\title{
Multiple factors influence local perceptions of snow leopards and Himalayan wolves in the central Himalayas, Nepal
}

\author{
Madhu Chetri ${ }^{\text {Corresp., }}{ }^{1}$, Morten Odden $^{1}$, Olivier Devineau ${ }^{1}$, Thomas McCarthy $^{2}{ }^{2}$ Per Wegge ${ }^{3}$ \\ ${ }^{1}$ Faculty of Applied Ecology, Agricultural Sciences and Biotechnology, Inland Norway University of Applied Sciences, NO-2480 Koppang, Norway \\ 2 Panthera, New York, USA \\ 3 Faculty of Environmental Sciences and Natural Resource Management, Norwegian University of Life Sciences, NO-1432 Ås, Norway \\ Corresponding Author: Madhu Chetri \\ Email address: madhu.chetri@inn.no
}

An understanding of local perceptions of carnivores is important for conservation and management planning. In the central Himalayas, Nepal, we interviewed 428 individuals from 85 settlements using a semi-structured questionnaire to quantitatively assess local perceptions and tolerance of snow leopards and wolves. We used generalized linear mixed effect models to assess influential factors, and found that tolerance of snow leopards was much higher than of wolves. Interestingly, having experienced livestock losses had a minor impact on perceptions of the carnivores. Occupation of the respondents had a strong effect on perceptions of snow leopards but not of wolves. Literacy and age had weak impacts on snow leopard perceptions, but the interaction among these terms showed a marked effect, i.e. being illiterate had a more marked negative impact among older respondents. Among the various factors affecting perceptions of wolves, numbers of livestock owned and gender were the most important predictors. People with larger livestock herds were more negative towards wolves. In terms of gender, males were more positive to wolves than females, but no such pattern was observed for snow leopards. People's negative perceptions towards wolves were also related to the remoteness of the villages. Factors affecting people's perceptions could not be generalized for the two species, and thus need to be addressed separately. We suggest future conservation projects and programs should prioritize remote settlements. 
1 Title: Multiple factors influence local perceptions of snow leopards and Himalayan wolves

2 in the central Himalayas, Nepal.

3 Madhu Chetri ${ }^{1}$, Morten Odden ${ }^{1}$, Olivier Devineau ${ }^{1}$, Thomas M. McCarthy ${ }^{2}$, Per Wegge ${ }^{3}$

$4{ }^{1}$ Faculty of Applied Ecology, Agricultural Sciences and Biotechnology, Inland Norway

5 University of Applied Sciences, NO-2480 Koppang, Norway

62 Panthera, New York, NY, 10018, USA

$7 \quad{ }^{3}$ Faculty of Environmental Sciences and Natural Resource Management, Norwegian University

8 of Life Sciences, NO-1432 Ås, Norway

9

10 Corresponding Author:

11 Madhu Chetri

12 Anne Evenstads vei 80

13 2480, Koppang, Norway

14 Email: mchetri@gmail.com; madhu.chetri@inn.no 


\section{Abstract}

An understanding of local perceptions of carnivores is important for conservation and management planning. In the central Himalayas, Nepal, we interviewed 428 individuals from 85 settlements using a semi-structured questionnaire to quantitatively assess local perceptions and tolerance of snow leopards and wolves. We used generalized linear mixed effect models to assess influential factors, and found that tolerance of snow leopards was much higher than of wolves. Interestingly, having experienced livestock losses had a minor impact on perceptions of the carnivores. Occupation of the respondents had a strong effect on perceptions of snow leopards but not of wolves. Literacy and age had weak impacts on snow leopard perceptions, but the interaction among these terms showed a marked effect, i.e. being illiterate had a more marked negative impact among older respondents. Among the various factors affecting perceptions of wolves, numbers of livestock owned and gender were the most important predictors. People with larger livestock herds were more negative towards wolves. In terms of gender, males were more positive to wolves than females, but no such pattern was observed for snow leopards. People's negative perceptions towards wolves were also related to the remoteness of the villages. Factors affecting people's perceptions could not be generalized for the two species, and thus need to be addressed separately. We suggest future conservation projects and programs should prioritize remote settlements.

Keywords: Panthera uncia, Canis lupus chanco, perceptions, large carnivores, trans-Himalayas. 


\section{INTRODUCTION}

38 Large carnivore co-existence with humans remains a global challenge (Athreya et al., 2013), and mitigation of human-carnivore conflicts requires multiple approaches and disciplines (Redpath et al., 2013). Among the various aspects of carnivore conflict management, understanding local perceptions is crucial for establishing long term conservation strategies (Bagchi \& Mishra, 2006; Conforti \& Azevedo, 2003), especially in multi-use landscapes where animal husbandry is the main source of income. An assessment of local perceptions helps in identifying groups of people or villages that are negative towards protection of carnivores, and thus aids conservation authorities to find suitable strategies to improve their tolerance (Suryawanshi, 2013; Treves \& Karanth, 2003). Further, assessments form a basis for quantifying the effects of conservation management interventions and aid in formulating new strategies if opinions towards conservation change (Dressel, Sandström \& Ericsson, 2015).

Globally, local perceptions and attitudes towards large carnivores are complex and vary markedly between regions (Røskaft et al., 2007). Multiple factors influence local perceptions, including animal behavior, risk of negative encounters, and the length of the period of coexistence (Dickman, 2010; Dressel, Sandström \& Ericsson, 2015; Kellert et al., 1996; Zimmermann, Wabakken \& Dötterer, 2001). Local perceptions also vary among ethnic groups, and are linked to religious- and cultural beliefs (Ale, Shah \& Jackson, 2016; Dickman et al., 2014; Kellert et al., 1996; Li et al., 2013; Mkonyi et al., 2017). Socio-demographic variables

57 such as age, sex, income, occupation, literacy, number of livestock owned and loss to predators

58 have all shown to be associated with local perceptions and attitudes of large carnivores (Caruso 
59

60

61

62

63

64

65

66

67

68

et al., 2020; Fort et al., 2018; Kellert \& Berry, 1987; Kideghesho et al., 2007; Naughton-Treves, Grossberg \& Treves, 2003; Oli, Taylor \& Rogers, 1994; Røskaft et al., 2007; Trajçe et al., 2019).

In the central Himalayas, Snow leopards (Panthera uncia) and Himalayan wolves (Canis lupus chanco) are the two most important predators involved in conflicts with people (Chetri et al., 2019a). A recent study from the region revealed that snow leopards were responsible for the majority of predation losses $(61.9 \%)$; the remaining were from Himalayan wolf $(16.8 \%)$ and other predators (21.3\%) including feral dogs (Canis lupus familiaris), brown bear (Ursus arctos), black bear (Ursus thibetanus), Eurasian lynx (Lynx lynx), golden jackal (Canis aureus) and common leopard (Panthera pardus) (Chetri et al., 2019a). The snow leopard is categorized as Vulnerable in the IUCN red list of threatened species (McCarthy et al., 2017), whereas wolf is considered as Least Concern (Boitani, Phillips \& Jhala, 2018). However, in the national Red Data List of Nepal, wolves are considered as Critically Endangered and snow leopards are considered as Endangered (Jnawali et al., 2011). A recent fecal DNA study reported that the snow leopard density within our study area in the central Himalayas was 0.95 (SE 0.19) animals per $100 \mathrm{~km}^{2}$ (Chetri et al., 2019b), but density estimates of wolves from the area are still lacking (WWF, 2015; Chetri et al., 2016; Chetri, Odden \& Wegge, 2017). The species has received little conservation attention due to its lower conservation status in the IUCN Red list, which has made it difficult to acquire necessary funding for population monitoring. According to Chetri (2014), Himalayan wolves are rare in the region and mostly solitary. The wolves that thrive in this landscape are genetically unique to the region as revealed by recent DNA analysis, and they are considered different from the grey wolf lineage (Chetri et al., 2016). Both species range widely and often encounter pastoralists. 
83 Although information on livestock depredation by snow leopards and wolves exists from Nepal's

Himalaya (Aryal et al., 2014; Chetri, Odden \& Wegge, 2017 ; Chetri et al., 2019a; Oli, Taylor \& Rogers, 1994; Wegge, Shrestha \& Flagstad, 2012; Werhahn et al., 2019), limited information is available regarding variation in local perceptions and tolerance to these species on a large spatial scale (Hanson et al., 2019; Kusi et al., 2019; Oli, Taylor \& Rogers 1994). Hence, in our study, we examined local communities' perceptions of snow leopards and wolves in a large area of $\sim 5000 \mathrm{~km}^{2}$ where livestock depredation has been a main concern in recent decades. The survey covered two protected areas, Annapurna Conservation Area (ACA, hereafter) and Manaslu Conservation Area (MCA, hereafter), where ecological studies of snow leopard and wolf had recently been conducted (Chetri, 2018). These studies showed that snow leopard density was far lower than previously assumed, and consequently, average annual livestock losses were low (ca.1\%) even though livestock constituted large proportions of the diet of both snow leopards and wolves (ca.25\%). Despite the low levels of livestock depredation, perceptions of wolves are often negative. Similarly, incidents of mass killings of livestock by snow leopards decreases local tolerance towards their conservation, which in turn may lead to retaliatory killing of carnivores (Jackson, 2015; Mishra, Redpath \& Suryawanshi, 2016; Mishra et al., 2004;

Suryawanshi et al., 2014; Woodroffe et al., 2005). Surplus killings and injuries of high valued livestock (e.g. horses, milking yaks and cows) not only outrage local communities (Oli, Taylor \& Rogers, 1994), but also have negative repercussion that can spread even to distant villages.

\section{Integrated conservation and development efforts that were initiated in ACA and MCA in the} 1990-ies included conservation awareness campaigns principally targeting snow leopard, but not 
105

106

107

108

109

110

111

112

113

114

115

116

117

118

119

120

121

122

123

124

125

126

127

wolves. Due to the relatively low livestock losses and the considerable conservation efforts in the study area, we expected perceptions of carnivores to be more positive than reported from previous studies from the Himalayan range. Furthermore, we expected perceptions to vary geographically as well as between species due to a bias in the impact of conservation awareness campaigns, i.e. tolerance of wolves should be lower, and perceptions could potentially depend on the remoteness of villages. Lastly, we expected perceptions to be affected by socioeconomic and demographic factors, e.g. livestock losses and ownership, gender, age, education and occupation.

\section{MATERIAL AND METHODS}

\section{Ethics statement}

Approval and relevant permits required to carry out this research were obtained from the National Trust for Nature Conservation (Ref.no.291), Nepal.

\section{Study area}

We conducted the study in the Annapurna - Manaslu Conservation landscape in the central Himalayas (N28 - 29, E83 - 85 ; Fig.1). Both ACA and MCA are located within this landscape and are the largest community-based conservation areas in Nepal (ca.9292 $\left.\mathrm{km}^{2}\right)$. It is located in the rain shadow area of the Himalayas. Together with Bhimthang valley, it is the priority landscape for snow leopards conservation in the country (DNPWC, 2017). The human population density is 1 per $\mathrm{km}^{2}(\mathrm{CBS}, 2012)$, and agro-pastoralism is the main source of livelihood, although some households are also involved in eco-tourism related entrepreneurs. The overall livestock density in the study area is $35.74 \pm 0.10 / \mathrm{km}^{2}$ (Chetri, Odden \& Wegge, 2017). All accessible areas are used for livestock grazing following the seasonal traditional Tibetan calendar (Chetri et al., 2019a). Grazing areas are designated for seasonal grazing as 
128 summer and winter. Areas close to villages are used for year-round grazing (Fig. 1). Livestock,

129 for example sheep, goats and cows are usually herded and periodically moved among different

130 pastures according to seasons (Chetri, Odden \& Wegge, 2017). Small stocks (sheep and goats)

131 are herded and sometimes accompanied by herding dogs. They are released in the morning and

132 brought back to corrals/pens in the afternoon on a regular basis. Similarly, milking cows and,

133 yaks are brought back to corrals/pens in the afternoon or in the morning for milking. Livestock

134 are kept in corrals/pens for protection against predators corrals are traditionally made of mud

135 walls and stones.

136

137 Over the last decade there have been considerable changes in the lifestyle of the local people due 138 to the development of roads in ACA. Despite these changes, traditional agro-pastoral lifestyles 139 remain intact, and most importantly, traditional livestock grazing and collective village level 140 decision making and implementation is still functional. In ACA, most farmers prefer to raise 141 goats (Capra hircus) and sheep (Ovis aries) due to abundant pastureland, whereas in MCA

142 farmers prefer cattle-yak hybrids (dzo, Jhopas, Bos spp.) as they are both grazers and browsers.

143 Similarly, in the central part of ACA, farmers prefer yaks (Bos grunniens) due to dominant scrub 144 vegetation. Lulu cows (Bos taurus sp.) and horses (Equus ferus caballus) are common in all 145 areas. Among the main wild ungulates, bharal (Pseudois nayaur) and Himalayan tahr 146 (Hemitragus jemlahicus) are widespread, whereas Tibetan argali (Ovis ammon hogdsoni), kiang 147 (Equus kiang), and Tibetan gazelle (Procapra picticaudata) have overlapping grazing areas with 148 livestock in the north-western parts of ACA. 
150 Apart from snow leopards and wolves, other carnivores include golden jackal, red fox (Vulpes

151 vulpes), Himalayan black bear, Tibetan sand fox (Vulpes ferrilata), brown bear, Eurasian lynx

152 and several species of weasel (Mustela spp.), and marten (Martes spp.).

153 Figure 1: Study area with location of survey villages and grazing areas.

154

155 Semi-structured questionnaire survey

156 To assess local perceptions and tolerance towards snow leopards and wolves, we administered a

157 semi-structured questionnaire (see supplemental materials for questionnaire structure, Appendix

158 S1). We randomly selected 428 households scattered over 85 settlements within 21 Village

159 Development Committee (VDC) units from July to September 2014. A VDC is the lowest rural 160 administrative unit and usually encompasses 7-9 small clustered villages or settlements know as 161 a ward. Recently, with the promulgation of the new constitution, the Nepal government dissolved 162 the VDC structure and established a new local body known as gaun palika or rural municipality. 163 But in this study we will use VDC as the data was collected prior to this change.

164 Each VDC has separate designated grazing areas. Among the 21 VDCs in the study area (6621 $165 \mathrm{~km}^{2}$ ), $2934 \mathrm{~km}^{2}(44.3 \%$ ) was used for livestock grazing (summer 55.6\%, winter 24.6\% and 19.8\% year-round). The remaining areas (ca.3687 $\mathrm{km}^{2}$ ) were inaccessible for livestock grazing 167 due to rugged terrain and high altitude (Fig. 1). Our survey covered $13 \%$ of the total number of 168 households within the survey villages (CBS, 2012). Due to scattered settlements/villages, vast 169 landscape and remoteness of the area, most of the questionnaires were conducted using locally 170 trained community members, managed through the Unit Conservation Offices (UCOs) of ACA 171 and MCA (Chetri et al., 2019a). Before the initiation of the survey, each interviewer was briefed 172 about the purpose of the study and trained in how to conduct the semi-structured questionnaire, 
173 and verbal consent was obtained from all subjects. The survey households were selected

174 following the main village trails. We approached the household closest to the main village trail

175 and selected every third household thereafter for interviews. If the inhabitants were absent, we

176 selected the nearest neighbor. For each respondent, we recorded the number of livestock owned,

177 herd composition and livestock loss to snow leopards and wolves during the previous year. We

178 also recorded respondent age, gender, education and occupation. We asked their opinion about

179 the presence of snow leopards and wolves near their grazing areas and homesteads, and

180 categorized their answers as positive, neutral and negative. We considered questionnaires as

181 invalid when respondents stated that they did not know about the species presence and conflict

182 (i.e., neutral responses). These questionnaires were excluded from the analyses. Hence, although

183 we administered similar questionnaire sets to assess perceptions of snow leopards and wolves,

184 the sample size for wolf perceptions became smaller due to a larger proportion of invalid

185 questionnaires (Table 1). This was mainly because wolves are found only in the northwestern

186 section of ACA and MCA (see Fig. 1).

\section{Data analysis}

188 We used generalized linear mixed effects models (GLMMs) to determine the relationship

189 between response and potential predictor variables with two separate sets of models, one for

190 snow leopards and one for wolves. GLMMs take into account random effects and provide a more

191 flexible approach for analyzing non-normal data (Bolker et al., 2009). As a binomial response

192 variable, we categorized opinions of presence of snow leopards and wolves as either positive or

193 negative, as described previously. As explanatory variables, we included factors and covariates

194 that were identified as important predictors of livestock losses in a previous study conducted in

195 the region (Chetri et al., 2019a), as well as demographic and socioeconomic variables that have 
196 been linked to perceptions of carnivores in previous studies (see e.g. Caruso et al., 2020; Kellert

197 \& Berry, 1987; Kusi et al., 2019; Oli, Taylor \& Rogers 1994; Suryawanshi et al., 2014): (i)

198 Ownership (number of livestock owned), (ii) herd composition (proportion of large stock relative

199 to all livestock owned, see Chetri et al., 2019a, (iii) number of livestock lost to snow leopards or

200 wolves, (iv) occupation (agro-pastoral, livestock herding, and others, i.e. respondents benefitting

201 from tourism, such as traders, hotel owners, tourist guides and porters), (v) literacy (ability to

202 read and write), (vi) gender, (vii) age, and (viii) distance to the nearest conservation office

203 (number of walking days required to reach nearest conservation field office - standardized to 8

204 hrs. walking/day). We did not include religion as a predictive factor as all the locals residing in

205 the region are Buddhist, only a few outsiders who are working as labor or teacher are non-

206 Buddhist. We standardized all numeric explanatory variables by two standard deviations,

207 following Gelman \& Hill (2007). VDC was used as a random effect in all models. We checked

208 correlation among (continuous) predictors before carrying out the regression analysis, and we did

209 not include collinear variables (rho $>0.6$ ) into the same model. We analyzed the data using $\mathrm{R}$

210 version 3.4.2 (R CoreTeam, 2017).

211

212 RESULTS

213 We used only 395 and 327 questionnaires in our analyses regarding snow leopards and wolves,

214 respectively (Table 1), due to the exclusion of respondents that were neutral or unaware of

215 species presence or conflicts. In terms of gender, more than $80 \%$ of the respondents were male

216 (Table 1), and approximately 50\% of the respondents were illiterate. Among occupations, most

217 respondents belonged to the agro-pastoralist category (Table 1). An analysis of respondents' 
218 perceptions in general revealed that local people were more negative towards wolves $(n=276$, $21984.4 \%)$ than towards snow leopards $(n=209,52.9 \%)$ (Table 1$).$

Table 1: Overview of respondent characteristics in the Annapurna-Manaslu landscape, central Himalayas, Nepal.

\section{Local perceptions of snow leopards}

We compared 22 candidate models to assess perceptions of snow leopards (Table S1). The two

highest ranking models had a small difference in $\mathrm{AICc}$ value $(\triangle \mathrm{AICc}=0.27)$ and Akaike weights $(0.45$ and 0.39$)$. Both models included the predictor variables occupation, sex and the interaction between age and literacy (Table 2). The top ranking model in terms of AICc also included ownership, but due to the marginal effect of removing this variable, we present here the simpler second ranking model (Fig. 2). The occupation of the respondents had a strong effect on their perceptions of snow leopards. Among the three categories of occupation, there was only a slight difference in perceptions between agro-pastoralists (income from both agriculture and

233 livestock) and herders (income solely from livestock herding). On the contrary, respondents with other additional sources of income (e.g. tourism) were far more positive towards snow leopards (i.e. OCCOTHER, Fig. 2). Furthermore, sex was included in the model, but the effect was weak, i.e. men were more positive towards snow leopards than women. The main effects of literacy and age had very weak impacts on perceptions, but the interaction between these terms showed a the older respondents.

\section{Local perceptions of wolves}


241 We compared 24 candidate models to assess perceptions of wolves (Table S2). The highest

242 ranking model performed far better than the other candidates (Akaike weight $=0.70$, Table 2).

243 This model included different predictors than the model for snow leopards, i.e. sex and

244 ownership (Fig. 3). In this case, male respondents were markedly more positive than females.

245 Other predictor variables were livestock loss (numbers lost to wolves), herd composition,

246 distance to the nearest conservation field office and livestock ownership. The latter predictor had

247 a marked effect on perceptions, i.e. respondents with larger herds were more negative.

Table 2: Model selection for perception towards the snow leopard and the wolf.

250

251

Figure 2: Parameter estimates based on Generalized Linear Mixed-Effects Models of

factors affecting perceptions of snow leopards.

253

254

Figure 3: Parameter estimates based on Generalized Linear Mixed-Effects Models of

factors affecting perceptions to Himalayan wolves.

\section{DISCUSSION}

258

259

260

261

262

263

264

In our study landscape, a far larger proportion of respondents were negative towards wolves than to snow leopards. This was also observed by Kusi et al. (2019) in upper Dolpa and Humla areas, located in the western region of Nepal. This perception is common in areas where wolves coexist with other large predators, for example brown bear and lynx (Trajçe et al., 2019). A possible cause is related to the difference in behavior of wolves compared to other carnivores. Snow leopards are cryptic, avoid humans and are more nocturnal than wolves (McCarthy, Fuller \& Munkhtsog, 2005; Mech \& Boitani, 2010). Wolves are more active during the day and attack 
265 livestock both during day and night (Xu, Yang \& Dou, 2015). Furthermore, research has shown

266 that greater visibility and howling behavior of wolves may reinforce negative perceptions

267 (Kellert et al., 1996).

268

269 Social norms and cultural beliefs also play an important role in perceptions of the two carnivores.

270 Cultural sentiments, religious belief and folklore associated with snow leopards have a strong

271 positive influence on their conservation (Ale, Shah \& Jackson, 2016; Li et al., 2014). Further, the

272 local practice of non-violence (e.g. Tsum valley of MCA) and protection of forest and landscape

273 in the name of monasteries (Li et al., 2014) have also played an important role in snow leopard

274 conservation. The Buddhist communities to which most of our respondents belong traditionally

275 do not kill wildlife because it was considered a sin in their religion (Li et al., 2014). The snow

276 leopard is often considered as a symbol of the mountains, and the charisma of the species

277 promotes attention both in terms of research and conservation efforts from global and national

278 conservation authorities (McCarthy et al., 2016). In contrast, wolves are traditionally depicted as

279 merciless and evil creatures in legends and folklore (Dingwall, 2001; Marvin, 2012). A recent

280 study from Spiti, India showed that more than $98 \%$ of the survey respondents claimed that

281 wolves were not safe for livestock and their presence was highly disliked by the communities

282 (Lyngdoh \& Habib, 2019). Similar trends have been observed in parts of Europe (Dingwall,

283 2001; Marvin, 2012) and America (Grima, Brainard \& Fisher, 2019). This is not surprising as

284 dislike to wolves is common across the globe (Bhatia et al., 2016; Dressel, Sandström \&

285 Ericsson, 2015; Kansky, Kidd \& Knight, 2014; Kusi et al., 2019; Lyngdoh \& Habib, 2019;

286 Suryawanshi et al., 2014). The negative perceptions of the wolf in our study area thus probably 
287 due to fear and cultural bias as reported in many other studies (Linnell et al., 2002; Prokop, Usak

288 \& Erdogan, 2011), an issue to be considered in future conservation plans in ACA and MCA.

289

290 In our study area, analysis of livestock depredation revealed higher losses from snow leopards

291 compared to wolves (Chetri et al., 2019a), but still the tolerance level of local communities

292 towards snow leopards was higher. Tolerance to snow leopards in ACA has changed to become

293 more positive compared with an earlier study (Oli, Taylor \& Rogers, 1994), probably as a result

294 of continued efforts to increase awareness as part of an ongoing conservation program (DNPWC,

295 2017). No such efforts have targeted wolves, or other coexisting carnivores in this area.

296

297 Our model revealed that literacy, age, occupation, number of livestock owned and gender

298 affected perceptions towards snow leopards and wolves. However, the predictors for the two

299 species were different (see Fig. 2 and 3), i.e. the latter two appeared in the best model for wolf

300 perceptions and the former three for snow leopard. Regarding literacy and age, only the

301 interaction between these terms had an influence on perceptions of snow leopards, but not the

302 main effects. Being illiterate was associated with negative perceptions among older respondents.

303 Possibly, younger people had more exposure to snow leopard conservation campaigns,

304 regardless of literacy. Several earlier studies have shown that older people are more negative

305 towards large predators and usually less supportive of their conservation than the younger

306 generation (Bencin, Kioko \& Kiffner, 2016; Kellert \& Berry, 1987; Kleiven, Bjerke \&

307 Kaltenborn, 2004; Røskaft et al., 2007; Williams, Ericsson \& Heberlein, 2002). 
309 Occupation influenced perceptions of snow leopards, i.e. people with sources of income other 310 than animal husbandry were more positive. Elsewhere, it was also reported that people having

311 smaller landholdings and few economic opportunities other than livestock herding are more

312 negative towards snow leopards and wolves (Bagchi \& Mishra, 2006; Din et al., 2017). In a

313 study of jaguars (Panthera onca), Caruso et al. (2020) found a similar pattern; people's

314 perceptions and attitudes were strongly influenced by occupation and economic benefits through

315 ecotourism. In Ladakh, India snow leopard based ecotourism has become popular and provides

316 income generation opportunities to the local communities (Jackson, 2015; Maheshwari \&

317 Sathyakumar, 2019; Vannelli et al., 2019).

319 Regarding perceptions of wolves, males were more positive than females. This pattern was also reported in earlier studies (Kellert \& Berry, 1987; Røskaft et al., 2007; Suryawanshi et al., 2014), and has been explained by women having less contact with conservation agencies (Gillingham

$322 \&$ Lee, 1999). Another study suggested that the negative attitudes of women might be a result of

323 greater perception of risk or fear (Prokop \& Fančovičová, 2010). As suggested by Kusi et al.

324 (2019), men in the Himalayas often migrate outside of villages for seasonal work and may thus

325 have been more exposed to alternative attitudes to nature and conservation. In addition, men

326 frequently venture into the pasture for livestock grazing activities and presumably had more

327 encounters with wolves, which make them understand their behaviour and threats. High

328 encounter rates with wolves either in the wild or in captivity, may promote more positive 329 perceptions of the animals (Arbieu et al., 2020). 
331 People holding large livestock herds were more negative towards wolves, which agrees with a

332 study from western China (Xu, Yang \& Dong, 2015). A possible explanation is that owners with

333 larger herds have a higher risk of suffering losses in the central Himalayas, especially farmers

334 having a larger herd of goat/sheep (Chetri, Odden \& Wegge, 2017). It is, however, notable that

335 having experienced losses did not affect perceptions of snow leopards, and the effect of

336 perception on wolves was weak. This is in contrast with a recent study from the Nepal

337 Himalayas where livestock depredation by wolves is the main predictor of the negative attitude

338 towards wolves (Kusi et al., 2019). However, such a pattern was not recorded in our study area

339 and may be due to the fact that average losses in our study area were quite low $(\sim 1 \%$ of all

340 livestock holdings).

341

342 In our study area, the National Trust for Nature Conservation (NTNC) has been implementing

343 community-based conservation projects and programs since 1992 . The overall goal is to

344 conserve biodiversity of global significance with the active participation of local communities.

345 Integrated conservation and development efforts have therefore addressed the communities'

346 needs and demands while actively mobilizing local people in conservation efforts. However,

347 even after 2-3 decades of conservation initiatives, local perceptions and tolerance towards

348 carnivores are still rather negative, particularly towards wolves. We therefore recommend a

349 wider perspective of future awareness campaigns to include a broader specter of species and

350 conservation issues with particular efforts to the Himalayan wolf. During interviews, we

351 observed that remote settlements had rarely been visited by conservation authorities, and the

352 inhabitants there had limited knowledge of compensation policies for livestock losses and human

353 injury. Local perceptions on wolves tended to be more negative with increasing distances from 
354 conservation field offices, and this has been reported in earlier research in parts of ACA (Oli,

355 Taylor \& Rogers, 1994). The factors underlying negative perceptions of distant settlements are

356 probably due to a limited local involvement in community conservation programs. In the future,

357 distant and remote settlements require more rigorous conservation outreach and awareness

358 activities.

359

360 CONCLUSIONS

361 This study has investigated local villagers' perception of snow leopards and wolves in the central

362 Himalayas, Nepal. In general, the perceptions of locals were more positive towards snow

363 leopards than to wolves. People having larger herds of livestock (goat/sheep) with limited access

364 to conservation programs were more likely to have negative perceptions towards wolves. Our

365 results showed that multiple factors influence local perceptions of the two carnivores and that

366 perception factors cannot be generalized for the two species. Thus, they need to be addressed

367 separately. We suggest that future conservation projects and programs prioritize remote

368 settlements. Furthermore, considering the substantial influence of occupation on people's

369 perceptions of carnivores, certain parts of the landscape, for example Manang of ACA and Tsum

370 valley of MCA, should be tested for the development of wildlife based ecotourism.

372 ACKNOWLEDGEMENTS

373 We sincerely thank the survey participants, the field staff of ACA and MCA, and the local

374 communities for their support and collaboration during the field surveys. 
376

377

378

379

380

381

382

383

384

385

386

387

388

389

390

391

392

393

394

395

396

397

398

\section{REFERENCES}

Ale S, Shah KB, and Jackson RM. 2016. South Asia: Nepal. In: McCarthy T, and Mallon D, eds. Snow Leopards: Biodiversity of the World: Conservation from Genes to Landscapes. Amsterdam, The Netherlands.: Elsevier Academic Press, 471-479.

Arbieu U, Albrecht J, Mehring M, Bunnefeld N, Reinhardt I, and Mueller T. 2020. The positive experience of encountering wolves in the wild. Conservation Science and Practice2, e184 DOI : $\underline{10.1111 / \operatorname{csp} 2.184}$.

Aryal A, Brunton D, Ji W, Barraclough RK, and Raubenheimer D. 2014. Human-carnivore conflict: ecological and economical sustainability of predation on livestock by snow leopard and other carnivores in the Himalaya. Sustainability Science 9:321-329 DOI : $10.1007 / \mathrm{s} 11625-014-0246-8$.

Athreya V, Odden M, Linnell JD, Krishnaswamy J, and Karanth U. 2013. Big cats in our backyards: persistence of large carnivores in a human dominated landscape in India. PLoS One 8:e57872 DOI : 10.1371/journal.pone.0057872.

Bagchi S, and Mishra C. 2006. Living with large carnivores: predation on livestock by the snow leopard (Uncia uncia). Journal of Zoology 268:217-224 DOI : 10.1111/j.14697998.2005.00030.x.

Bencin H, Kioko J, and Kiffner C. 2016. Local people's perceptions of wildlife species in two distinct landscapes of Northern Tanzania. Journal for Nature Conservation 34:82-92 DOI : $\underline{10.1016 / j . j n c .2016 .09 .004 .}$

Bhatia S, Redpath SM, Suryawanshi K, and Mishra C. 2016. The relationship between religion and attitudes toward large carnivores in Northern India? Human Dimensions of Wildlife 22:30-42 DOI : $\underline{10.1080 / 10871209.2016 .1220034 .}$ 
399 Boitani L, Phillips M, and Jhala Y. 2018. Canis lupus . The IUCN Red List of Threatened 400 Species 2018: e.T3746A119623865. Available at

401

402

403

404

405

406

407

408

409

410

411

412

413

414

415

416

417

418

419

420

421 https://dx.doi.org/10.2305/IUCN.UK.2018-2.RLTS.T3746A119623865.en (accessed on 18 January 2020)

Bolker BM, Brooks ME, Clark CJ, Geange SW, Poulsen JR, Stevens MHH, and White J-SS. 2009. Generalized linear mixed models: a practical guide for ecology and evolution. Trends Ecol Evol 24:127-135 DOI :10.1016/j.tree.2008.10.008.

Caruso F, Perovic PG, Tálamo A, Trigo CB, Andrade-Díaz MS, Marás GA, Saravia D, SilleroZubiri C, and Altrichter M. 2020. People and jaguars: new insights into the role of social factors in an old conflict. Oryx:1-9 DOI : 10.1017/S0030605318001552.

CBS. 2012. National Population and Housing Census 2011 (Vol. 01). Kathmandu, Nepal: Central Bureau of Statistics.

Chetri M. 2014. Ecology and Conservation of the Wolves in Chitwan Annapurna Landscape of Nepal Himalayas. National Trust for Nature Conservation Technical Paper Series \# 002/2004. NTNC, Hariyo Ban Program.

Chetri M. 2018. Ecology of Snow Leopards in the Central Himalayas, Nepal. A PhD Thesis. Inland Norway University of Applied Sciences, Faculty of Applied Ecology, Agricultural Sciences and Biotechnology, Norway. Available at https://brage.inn.no/inn$\underline{\text { xmlui/bitstream/handle/11250/2572228/Chetri.pdf? sequence=1\&isAllowed }=y}$ (accessed on 18 January 2020)

Chetri M, Jhala YV, Jnawali SR, Subedi N, Dhakal M, and Yumnam B. 2016. Ancient Himalayan wolf (Canis lupus chanco) lineage in Upper Mustang of the Annapurna Conservation Area, Nepal. Zookeys:143-156 DOI : 10.3897/zookeys.582.5966. 
422 Chetri M, Odden M, Devineau O, and Wegge P. 2019a. Patterns of livestock depredation by

423

424

425

426

427

428

429

430

431

432

433

434

435

436

437

438

439

440

441

442

443 snow leopards and other large carnivores in the Central Himalayas, Nepal. Global Ecology and Conservation 17:e00536 DOI : 10.1016/j.gecco.2019.e00536.

Chetri M, Odden M, Sharma K, Flagstad Ø, and Wegge P. 2019b. Estimating snow leopard density using fecal DNA in a large landscape in north-central Nepal. Global Ecology and Conservation 17:e00548. DOI : 10.1016/j.gecco.2019.e00548.

Chetri M, Odden M, and Wegge P. 2017. Snow Leopard and Himalayan Wolf: Food Habits and Prey Selection in the Central Himalayas, Nepal. PLoS One 12:e170549 DOI : 10.1371/journal.pone.0170549.

Conforti VA, and Cesar Cascelli de Azevedo F. 2003. Local perceptions of jaguars (Panthera onca) and pumas (Puma concolor) in the Iguaçu National Park area, south Brazil. Biological Conservation 111:215-221 DOI : 10.1016/S0006-3207(02)00277-X.

Dickman A. 2010. Complexities of conflict: the importance of considering social factors for effectively resolving human-wildlife conflict. Animal Conservation 13:458-466 DOI : 10.1111/j.1469-1795.2010.00368.x.

Dickman AJ, Hazzah L, Carbone C, and Durant SM. 2014. Carnivores, culture and 'contagious conflict': Multiple factors influence perceived problems with carnivores in Tanzania's Ruaha landscape. Biological Conservation 178:19-27 DOI : $\underline{10.1016 / \text { j.biocon.2014.07.011. }}$

Din JU, Ali H, Ali A, Younus M, Mehmood T, Norma-Rashid Y, and Nawaz MA. 2017. Pastoralist-predator interaction at the roof of the world: Conflict dynamics and implications for conservation. Ecology and Society 22 DOI : 10.5751/ES-09348-220232. 
444 Dingwall S. 2001. Ravenous wolves and cuddly bears: predators in everyday language. Forest $445 \quad$ Snow and Landscape Research 76.

446

447

448

449

450

451

452

453

454

455

456

457

458

459

460

461

462

463

464

465

466

DNPWC. 2017. Snow Leopard Conservation Action Plan (2017-2012). Department of National Parks and Wildlife Conservation, Kathmandu, Nepal.

Dressel S, Sandström C, and Ericsson G. 2015. A meta-analysis of studies on attitudes toward bears and wolves across Europe 1976-2012. Conservation Biology 29:565-574 DOI : 10.1111/cobi. 12420 .

Fort JL, Nielsen CK, Carver AD, Moreno R, and Meyer NF. 2018. Factors influencing local attitudes and perceptions regarding jaguars Panthera onca and National Park conservation in Panama. Oryx 52:282-291 DOI: 10.1017/S0030605317001016.

Gelman A, and Hill J. 2007. Data analysis using regression and multilevel/hierarchical models. Analytical methods for social research. Cambridge University Press, Cambridge, UK.

Gillingham S, and Lee PC. 1999. The impact of wildlife-related benefits on the conservation attitudes of local people around the Selous Game Reserve, Tanzania. Environmental Conservation 26:218-228 DOI : 10.1017/S0376892999000302.

Grima N, Brainard J, and Fisher B. 2019. Are wolves welcome? Hunters' attitudes towards wolves in Vermont, USA. Oryx:1-6 DOI : $\underline{10.1017 / S 0030605319000061 .}$

Hanson JH, Schutgens M, and Leader-Williams N. 2019. What factors best explain attitudes to snow leopards in the Nepal Himalayas? PLoS One 14:e0223565 DOI : 10.1371/journal.pone.0223565.

Jackson RM. 2015. HWC Ten Years Later: Successes and Shortcomings of Approaches to Global Snow Leopard Conservation. Human Dimensions of Wildlife 20:310-316 DOI : $\underline{10.1080 / 10871209.2015 .1005856 .}$ 
467 Jnawali SR, Baral HS, Lee S, Acharya KP, Upadhayay GP, Panday M, Shrestha R, Joshi D,

468 Lamichhane BR, Griffiths J, Khatiwada AP, Subedi N, and Amin Rc. 2011. The Status of

469 Nepal's Mammals: The National Red List Series. . Kathmandu, Nepal: Department of

470 National Parks and Wildlife Conservation.

471 Kansky R, Kidd M, and Knight AT. 2014. Meta-Analysis of Attitudes toward Damage-Causing

472 Mammalian Wildlife. Conservation Biology 28:924-938 DOI: $10.1111 /$ cobi.12275.

473 Kellert SR, and Berry JK. 1987. Attitudes, knowledge, and behaviors toward wildlife as affected

$474 \quad$ by gender. Wildlife Society Bulletin (1973-2006) 15:363-371.

475 Kellert SR, Black M, Rush CR, and Bath AJ. 1996. Human culture and large carnivore

476 conservation in North America. Conservation Biology 10:977-990 DOI: 10.1046/j.1523-

477 1739.1996.10040977.x.

478

479

480

481

482

483

484

485

486

487

488

Kideghesho JR, Røskaft E, and Kaltenborn BP. 2007. Factors influencing conservation attitudes of local people in Western Serengeti, Tanzania. Biodiversity and Conservation 16:22132230 DOI : 10.1007/s10531-006-9132-8.

Kleiven J, Bjerke T, and Kaltenborn BP. 2004. Factors influencing the social acceptability of large carnivore behaviours. Biodiversity \& Conservation 13:1647-1658 DOI : 10.1023/B:BIOC.0000029328.81255.38.

Kusi N, Sillero-Zubiri C, Macdonald DW, Johnson PJ, and Werhahn G. 2019. Perspectives of traditional Himalayan communities on fostering coexistence with Himalayan wolf and snow leopard. Conservation Science and Practice n/a:e165 DOI: 10.1111/csp2.165.

Li J, Wang D, Yin H, Zhaxi D, Jiagong Z, Schaller GB, Mishra C, McCarthy TM, Wang H, Wu L, Xiao L, Basang L, Zhang Y, Zhou Y, and Lu Z. 2014. Role of Tibetan Buddhist 
monasteries in snow leopard conservation. Conservation Biology 28:87-94 DOI:

490 10.1111/cobi.12135.

491

492

493

494

495

496

497

498

499

500

501

502

503

504

505

506

507

508

509

510

511

Li J, Yin H, Wang D, Jiagong Z, and Lu Z. 2013. Human-snow leopard conflicts in the Sanjiangyuan Region of the Tibetan Plateau. Biological Conservation 166:118-123 DOI : 10.1016/j.biocon.2013.06.024.

Linnell J, Andersen R, Andersone Z, Balciauskas L, Blanco JC, Boitani L, Brainerd S, Breitenmoser U, Kojola I, and Liberg O. 2002. The fear of wolves: A review of wolf attacks on humans. NINA Oppdragsmelding 731: 1-65. Available at https://www.nina.no/archive/nina/PppBasePdf/oppdragsmelding/731.pdf (accessed on 08 January 2020)

Lyngdoh S, and Habib B. 2019. Predation by Himalayan Wolves: Understanding conflict, culture and co-existence amongst Indo-Tibetan community and large carnivores in High Himalaya. bioRxiv:2019.2012.2016.877936 DOI : 10.1101/2019.12.16.877936.

Maheshwari A, and Sathyakumar S. 2019. Snow leopard stewardship in mitigating humanwildlife conflict in Hemis National Park, Ladakh, India. Human Dimensions of Wildlife:1-5 DOI : $\underline{10.1080 / 10871209.2019 .1610815 .}$

Marvin G. 2012. Wolf: Reaktion Books.

McCarthy T, Mallon D, Jackson R, Zahler P, and McCarthy K. 2017. Panthera uncia . The IUCN Red List of Threatened Species 2017: e.T22732A50664030. Available at https://dx.doi.org/10.2305/IUCN.UK.2017-2.RLTS.T22732A50664030.en (accessed on 18 January 2020)

McCarthy T, Mallon D, Sanderson EW, Zahler P, and Fisher K. 2016. What is a snow leopard? Biogeography and Status Overview. In: McCarthy T, and Mallon D, eds. Snow Leopards: 
Biodiversity of the World: Conservation from Genes to Landscapes. Amsterdam, The Netherlands.: Elsevier Academic Press, 23-41.

514 McCarthy TM, Fuller TK, and Munkhtsog B. 2005. Movements and activities of snow leopards

515 in Southwestern Mongolia. Biological Conservation 124:527-537 DOI :

$516 \quad \underline{10.1016 / \mathrm{j} . \text { biocon.2005.03.003. }}$

517 Mech LD, and Boitani L. 2010. Wolves: behavior, ecology, and conservation: University of $518 \quad$ Chicago Press.

519 Mishra C, Redpath SR, and Suryawanshi KR. 2016. Livestock predation by snow leopards: conflicts and the search for solutions In: McCarthy T, and Mallon D, eds. Snow Leopards: Biodiversity of the World: Conservation from Genes to Landscapes Amsterdam, The Netherlands.: Elsevier Academic Press, 59-67.

Mishra C, Van Wieren SE, Ketner P, Heitkönig I, and Prins HH. 2004. Competition between domestic livestock and wild bharal Pseudois nayaur in the Indian Trans-Himalaya. Journal of Applied Ecology 41:344-354 DOI : 10.1111/j.0021-8901.2004.00885.x.

Mkonyi FJ, Estes AB, Msuha MJ, Lichtenfeld LL, and Durant SM. 2017. Socio-economic correlates and management implications of livestock depredation by large carnivores in the Tarangire ecosystem, northern Tanzania. International Journal of Biodiversity Science, Ecosystem Services \& Management 13:248-263 DOI : $\underline{10.1080 / 21513732.2017 .1339734 .}$

Naughton-Treves L, Grossberg R, and Treves A. 2003. Paying for Tolerance: Rural Citizens' Attitudes toward Wolf Depredation and Compensation. Conservation Biology 17:15001511 DOI : $\underline{10.1111 / \mathrm{j} .1523-1739.2003 .00060 . x}$. 
534 Oli MK, Taylor IR, and Rogers ME. 1994. Snow leopard Panthera uncia predation of livestock:

535 an assessment of local perceptions in the Annapurna Conservation Area, Nepal.

536 Biological Conservation 68:63-68.

537 Prokop P, and Fančovičová J. 2010. Perceived Body Condition is Associated with fear of a Large

538 Carnivore Predator in Humans. Annales Zoologici Fennici 47:417-425, 419 DOI :

$539 \quad \underline{10.5735 / 086.047 .0606 .}$

540 Prokop P, Usak M, and Erdogan M. 2011. Good predators in bad stories: crosscultural

541 comparison of children's attitudes towards wolves. Journal of Baltic Science Education

$542 \quad 10: 229-242$.

543 R CoreTeam. 2017. R: a language and environment for statistical computing. Vienna, Austria: R

$544 \quad$ Foundation for Statistical Computing; 2017.

545 Redpath SM, Young J, Evely A, Adams WM, Sutherland WJ, Whitehouse A, Amar A, Lambert

546 RA, Linnell JD, and Watt A. 2013. Understanding and managing conservation conflicts.

547 Trends Ecol Evol 28:100-109 DOI : 10.1016/j.tree.2012.08.021.

548 Røskaft E, Händel B, Bjerke T, and Kaltenborn BP. 2007. Human attitudes towards large

549 carnivores in Norway. Wildlife Biology 13:172-185 DOI : 10.2981/0909-

$550 \quad$ 6396(2007)13[172:HATLCI]2.0.CO;2.

551 Suryawanshi KR. 2013. Human-Carnivore Conflicts: Understanding predation ecology and

552 livestock damage. A Thesis Submitted for the Degree of Doctor of Philosopy. Manipal

$553 \quad$ University, Manipal, India. Available at

554 https://shodhganga.inflibnet.ac.in/handle/10603/12251 (accessed on 08 January 2020) 
555 Suryawanshi KR, Bhatia S, Bhatnagar YV, Redpath S, and Mishra C. 2014. Multiscale factors

556 affecting human attitudes toward snow leopards and wolves. Conserv Biol 28:1657-1666

$557 \quad$ DOI : $10.1111 /$ cobi.12320.

558 Trajçe A, Ivanov G, Keçi E, Majić A, Melovski D, Mersini K, Mustafa S, Skrbinšek T, Stojanov

559 A, and Todorovska A. 2019. All carnivores are not equal in the rural people's view.

560 Should we develop conservation plans for functional guilds or individual species in the

561 face of conflicts? Global Ecology and Conservation:e00677 DOI :

562 10.1016/j.gecco.2019.e00677.

563 Treves A, and Karanth KU. 2003. Human-carnivore conflict and perspectives on carnivore management worldwide. Conservation Biology 17:1491-1499 DOI : $\underline{10.1111 / \mathrm{j} .1523-}$ 1739.2003.00059.x.

566

567

568

569

570

571

572

573

574

575

576

577

Vannelli K, Hampton MP, Namgail T, and Black SA. 2019. Community participation in ecotourism and its effect on local perceptions of snow leopard (Panthera uncia) conservation. Human Dimensions of Wildlife 24:180-193 DOI : 10.1080/10871209.2019.1563929.

Wegge P, Shrestha R, and Flagstad Ø. 2012. Snow leopard Panthera uncia predation on livestock and wild prey in a mountain valley in northern Nepal: implications for conservation management. Wildlife Biology 18:131-141 DOI: 10.2981/11-049.

Werhahn G, Kusi N, Li X, Chen C, Zhi L, Martín RL, Sillero-Zubiri C, and Macdonald DW. 2019. Himalayan wolf foraging ecology and the importance of wild prey. Global Ecology and Conservation 20:e0780 DOI : 10.1016/j.gecco.2019.e00780.

Williams CK, Ericsson G, and Heberlein TA. 2002. A quantitative summary of attitudes toward wolves and their reintroduction (1972-2000). Wildlife Society Bulletin:575-584. 
578 Woodroffe R, Lindsey P, Romañach S, Stein A, and ole Ranah SMK. 2005. Livestock predation

579 by endangered African wild dogs (Lycaon pictus) in northern Kenya. Biological

$580 \quad$ Conservation 124:225-234 DOI : 10.1016/j.biocon.2005.01.028.

581 WWF. 2015. Non-Invasive Genetic Population Survey of Snow Leopard and Wolf. Final report. 582 WWF, Kathmandu, Nepal.

583 Xu Y, Yang B, and Dou L. 2015. Local villagers' perceptions of wolves in Jiuzhaigou County, $584 \quad$ western China. PeerJ 3:e982 DOI : $10.7717 /$ peerj.982.

585 Zimmermann B, Wabakken P, and Dötterer M. 2001. Human-carnivore interactions in Norway:

586 How does the re-appearance of large carnivores affect people's attitudes and levels of 587 fear. Forest Snow and Landscape Research 76:1-17. 
Figure 1

Study area with location of survey villages and grazing areas.

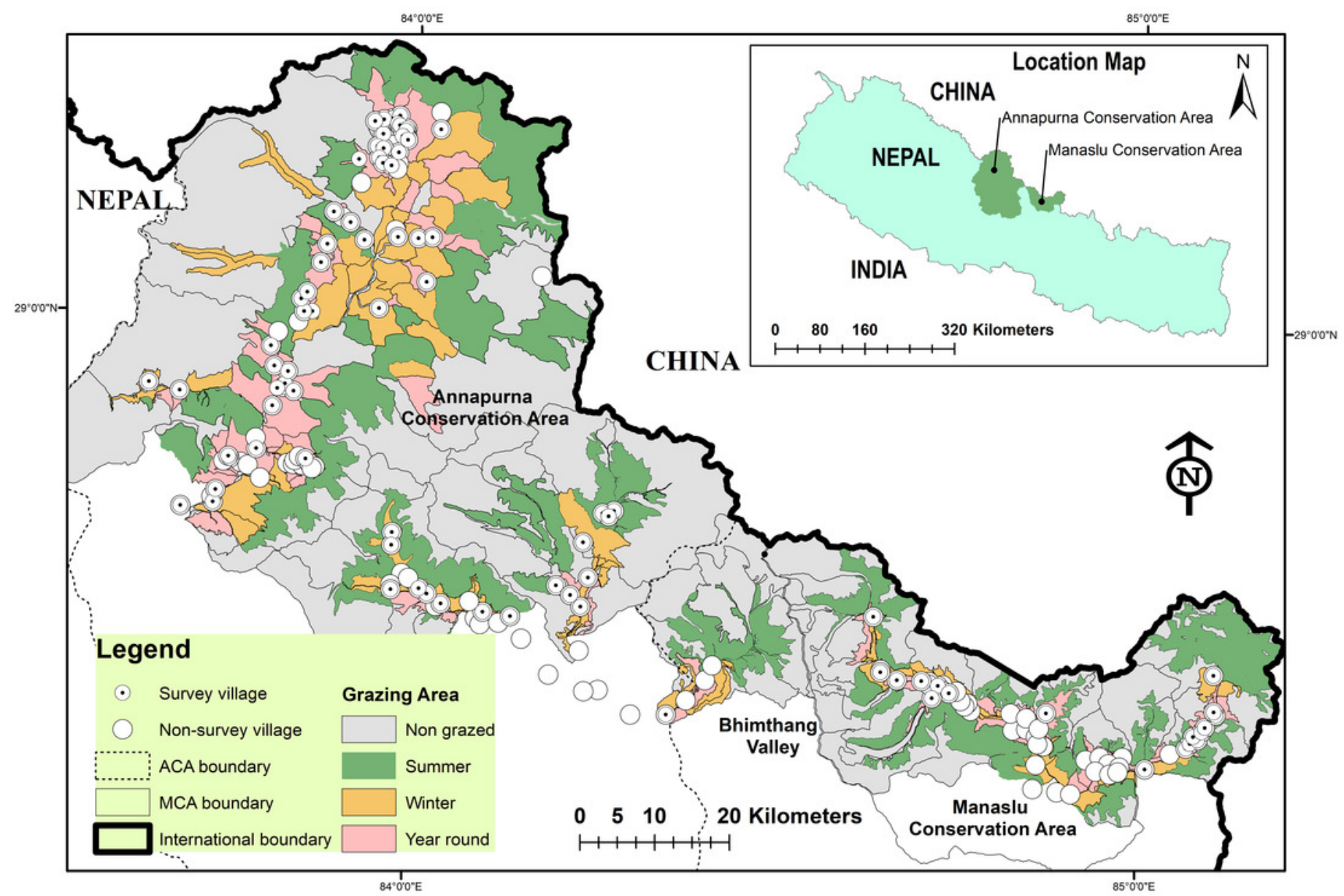




\section{Figure 2}

Figure 2 Parameter estimates based on Generalized Linear Mixed-Effects Models of factors affecting perceptions of snow leopards.

Dots and solid lines represent parameter estimates and $95 \% \mathrm{Cl}$. The estimates are on the logit scale. The strength of the effect of parameters is indicated by the distances between the solid horizontal lines and the dotted vertical line. VDC (Village Development Committee) is included as a random effect. OCCOTHER=Occupation-Others, LITyes= Literate (read and write), OCCHERD= Occupation-Herding, $\mathrm{SEXM}=$ Male, OWN=Total livestock holding, AGE=Age of the respondent, AGE:LITyes= the interaction between the respondent's age (AGE) and literacy (LITyes). 


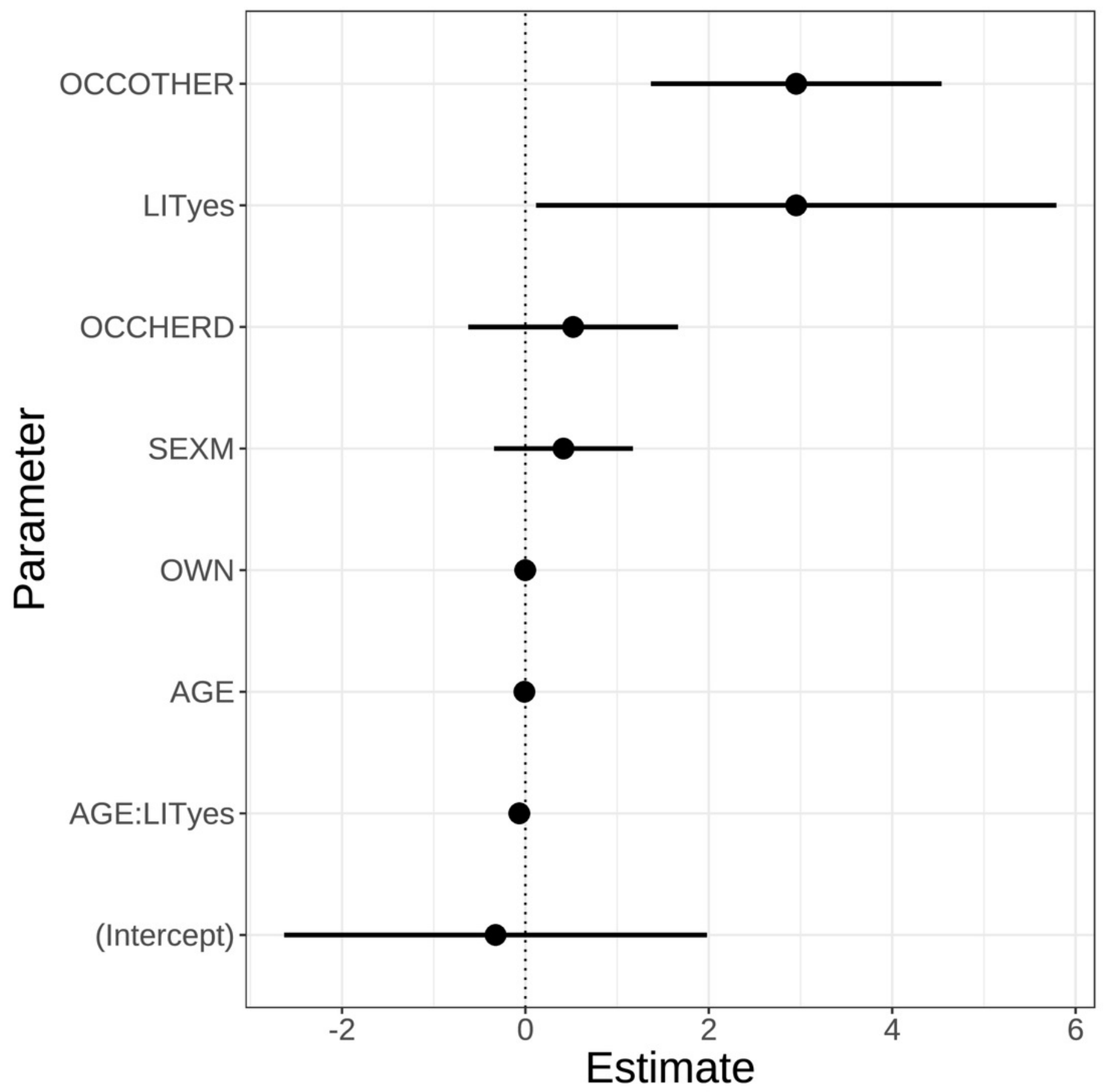




\section{Figure 3}

Figure 3 Parameter estimates based on Generalized Linear Mixed-Effects Models of factors affecting perceptions to Himalayan wolves.

Dots and solid lines represent parameter estimates and $95 \% \mathrm{Cl}$. The estimates are on the logit scale. The strength of the effect of parameters is indicated by the distances between the solid horizontal lines and the dotted vertical line. VDC (Village Development Committee) is included as a random effect. SEXM=Male, LOSS=Total livestock loss, COMP=Proportion of large livestock, DIST=Distance from the nearest conservation field office to respondent household, OWN=Total livestock holding. 


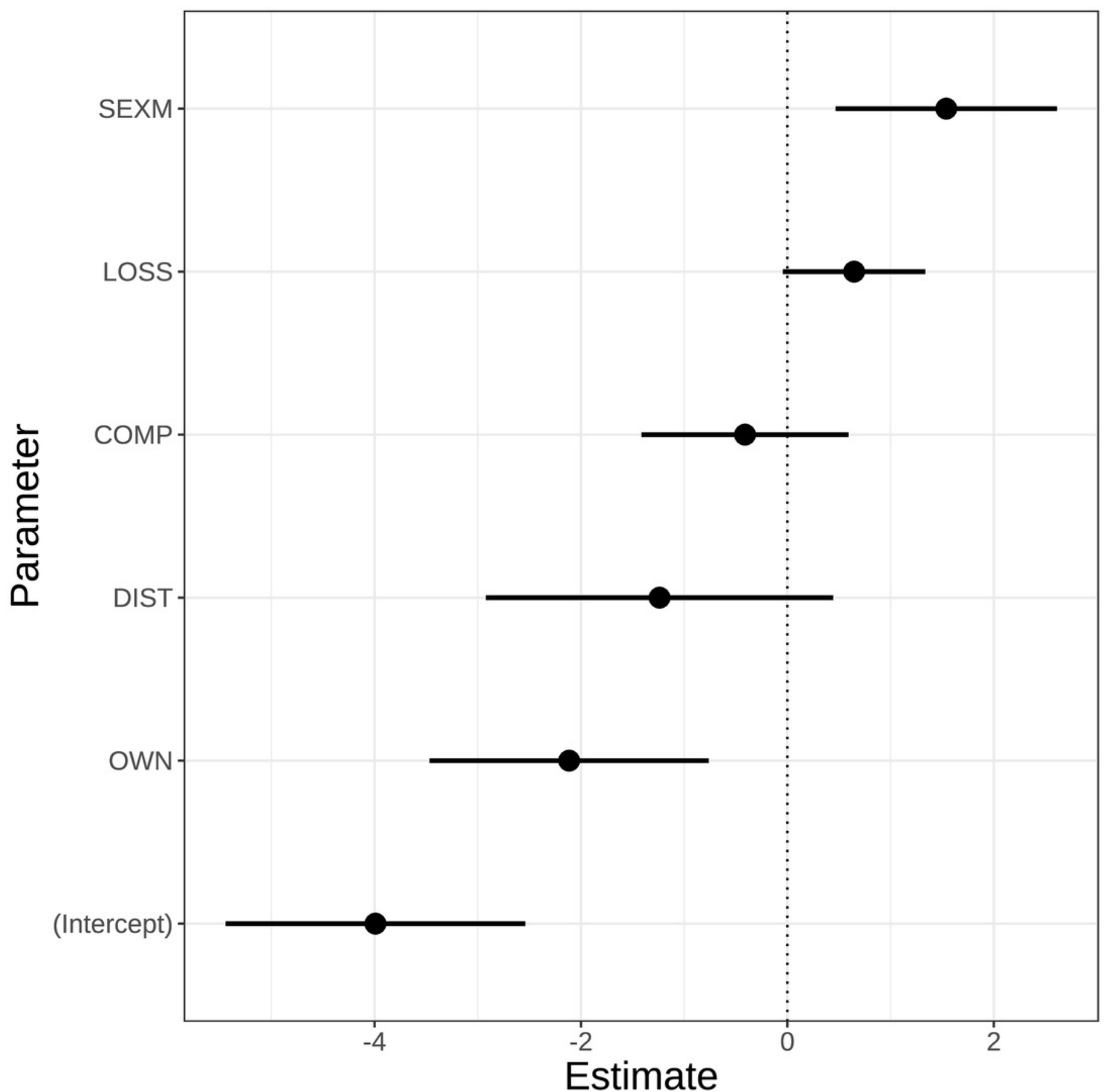




\section{Table $\mathbf{1}$ (on next page)}

Table 1 Overview of respondent characteristics in the Annapurna-Manaslu landscape, central Himalayas, Nepal.

Only respondents that responded to perceptions and share their experiences were included. Number in parenthesis indicates percentage of individual respondents in each category. ACA, Annapurna Conservation Area; MCA, Manaslu Conservation Area. 
1 Table 1: Overview of respondent characteristics in the Annapurna-Manaslu landscape,

2 central Himalayas, Nepal.

\begin{tabular}{|c|c|c|c|}
\hline & \multirow[b]{2}{*}{ Snow leopards } & \multirow[b]{2}{*}{ Wolves } \\
\hline & & & \\
\hline Number of questionnaires & & 428 & 428 \\
\hline Number of included/valid questionnaires & & $395(92.3)$ & $327(76.4)$ \\
\hline Number of invalid/excluded questionnaires & & $33(7.7)$ & $101(23.6)$ \\
\hline Village Development Committee (VDC) & & 21 & 14 \\
\hline Respondent age range (years) & & $20-87$ & $20-87$ \\
\hline Mean age (years) & & 46 & 46 \\
\hline \multirow[t]{2}{*}{ Region } & $\mathrm{ACA}$ & $353(89.4)$ & $296(90.5)$ \\
\hline & MCA & $42(10.6)$ & $31(9.5)$ \\
\hline \multirow[t]{2}{*}{ Gender } & Male & $331(83.8)$ & $270(82.6)$ \\
\hline & Female & $64(16.2)$ & $57(17.4)$ \\
\hline \multirow[t]{2}{*}{ Education } & Literate & $213(53.9)$ & $180(55.0)$ \\
\hline & Illiterate & $182(46.1)$ & $147(45.0)$ \\
\hline \multirow[t]{3}{*}{ Occupation } & Agro-pastoralist & $341(86.3)$ & $291(89.0)$ \\
\hline & Livestock herding & $30(7.6)$ & $13(4.0)$ \\
\hline & Others & $24(6.1)$ & $23(7.0)$ \\
\hline \multirow[t]{2}{*}{ Perceptions } & Positive & $186(47.1)$ & $51(15.6)$ \\
\hline & Negative & 209 (52.9) & $276(84.4)$ \\
\hline
\end{tabular}

\section{Notes.}

4 Only respondents that responded to perceptions and share their experiences were included.

5 Number in parenthesis indicates percentage of individual respondents in each category. 
6 ACA (hereafter), Annapurna Conservation Area.

7 MCA (hereafter), Manaslu Conservation Area. 


\section{Table 2 (on next page)}

Table 2 Model selection for perception towards the snow leopard and the wolf.

All continuous variables were standardized by 2 standard deviations (as per Gelman and Hill, 2007) and all models included a varying intercept on VDC (Village Development Committee). VDC is included as a random effect. AGE: age of the respondent, COMP: composition of the herd, i.e. proportion of large stock animals, LIT: literacy (yes / no), LOSS: number of domestic animals lost to the carnivore, OCC: respondent's occupation (Herding, Agriculture, Other), OWN: number of domestic animals owned, SEX: gender of the respondent. DIST=Distance from the nearest conservation field office to respondent household. Only the top 10 models are presented for each analysis. 
1 Table 2: Model selection for perception towards the snow leopard and the wolf.

Model

df logLik AICc delta weight

\section{Snow Leopard}

$\mathrm{OWN}+\mathrm{OCC}+\mathrm{SEX}+\mathrm{AGE} * \mathrm{LIT}$

$\begin{array}{lllll}9 & -233.24 & 484.9 & 0 & 0.45\end{array}$

$\mathrm{OCC}+\mathrm{SEX}+\mathrm{AGE} * \mathrm{LIT}$

$\begin{array}{lllll}8 & -234.42 & 485.2 & 0.27 & 0.39\end{array}$

$\mathrm{COMP} * \mathrm{LOSS}+\mathrm{OWN}+\mathrm{OCC}+\mathrm{SEX}+\mathrm{AGE} * \mathrm{LIT}$

$12-231.64$

$488.1 \quad 3.15 \quad 0.09$

$\mathrm{COMP} * \mathrm{LOSS}+\mathrm{OCC}+\mathrm{SEX}+\mathrm{AGE} * \mathrm{LIT}$

$\begin{array}{lllll}11 & -233.63 & 490 & 5.02 & 0.04\end{array}$

$\mathrm{COMP} * \mathrm{LOSS}+\mathrm{OWN}+\mathrm{OCC}+\mathrm{SEX}+\mathrm{AGE}$

$\begin{array}{lllll}10 & -234.74 & 490 & 5.11 & 0.04\end{array}$

OCC

$\begin{array}{lllll}4 & -245.06 & 498.2 & 13.28 & 0\end{array}$

$\mathrm{COMP} * \mathrm{LOSS}+\mathrm{OWN}+\mathrm{OCC}$

$\begin{array}{lllll}8 & -241.52 & 499.4 & 14.47 & 0\end{array}$

$\mathrm{COMP} * \mathrm{LOSS}+\mathrm{OWN}+\mathrm{OCC}+\mathrm{SEX}$

$\begin{array}{lllll}9 & -240.97 & 500.4 & 15.46 & 0\end{array}$

AGE

$\begin{array}{lllll}3 & -247.76 & 501.6 & 16.64 & 0\end{array}$

LIT

$\begin{array}{lllll}3 & -251.48 & 509 & 24.08 & 0\end{array}$

\section{Wolf}

$\mathrm{COMP}+\mathrm{DIST}+\mathrm{LOSS}+\mathrm{SEX}+\mathrm{OWN}$

$\begin{array}{llll}7 & -104.38 & 223.1 & 0\end{array}$

0.7

$\mathrm{COMP} * \mathrm{LOSS}+\mathrm{OWN}+\mathrm{OCC}+\mathrm{SEX}$

$\begin{array}{lllll}9 & -104.88 & 228.3 & 5.22 & 0.05\end{array}$

SEX

$\begin{array}{lllll}3 & -111.33 & 228.7 & 5.62 & 0.04\end{array}$

OWN

$\begin{array}{lllll}3 & -111.63 & 229.3 & 6.22 & 0.03\end{array}$

COMP + LOSS + OWN

$\begin{array}{lllll}5 & -109.59 & 229.4 & 6.26 & 0.03\end{array}$

COMP + LOSS + OWN + DIST

$\begin{array}{lllll}6 & -108.75 & 229.8 & 6.65 & 0.03\end{array}$ 


\begin{tabular}{|c|c|c|c|c|}
\hline $\mathrm{COMP} * \mathrm{LOSS}+\mathrm{OWN}+\mathrm{OCC}+\mathrm{SEX}+\mathrm{AGE}$ & 10 & -104.86 & 230.4 & 7.31 \\
\hline $\mathrm{OWN}+\mathrm{OCC}+\mathrm{SEX}+\mathrm{AGE} * \mathrm{LIT}$ & 9 & -106.05 & 230.7 & 7.56 \\
\hline $\mathrm{COMP}+\mathrm{LOSS} * \mathrm{OWN}$ & 6 & -109.26 & 230.8 & 7.67 \\
\hline COMP $*$ LOSS + OWN + LIT & 7 & -108.3 & 230.9 & 7.83 \\
\hline
\end{tabular}

\section{Notes.}

3 All continuous variables were standardized by 2 standard deviations (as per Gelman and Hill,

4 2007) and all models included a varying intercept on VDC (Village Development Committee).

5 VDC is included as a random effect. AGE: age of the respondent, COMP: composition of the

6 herd, i.e. proportion of large stock animals, LIT: literacy (yes / no), LOSS: number of domestic

7 animals lost to the carnivore, OCC: respondent's occupation (Herding, Agriculture, Other),

8 OWN: number of domestic animals owned, SEX: gender of the respondent. DIST=Distance from

9 the nearest conservation field office to respondent household. Only the top 10 models are

10 presented for each analysis. 